\title{
Technological features of biological protection of grain stocks against complex of phytophages of Lepidoptera (Pyralidae, Tineidae, Gelechiidae)
}

\section{Valentyn Drozda, Ilona Bondarenko}

National University of Life And Environmental Sciences Of Ukraine, Kyiv, Ukraine

Keywords:

Granary

Storage

Phytophages

Entomophage

Entomopathogen

Protection

Organics

\section{Article history:}

Received

12.01.2018

Received in revised form 23.03.2018

Accepted 29.03.2018

\section{Corresponding author:}

Ilona Bondarenko

E-mail:

ilona.bondarenko9@ gmail.com

DOI:

$10.24263 / 2304-$

974X-2018-7-1-8

\section{Abstract}

Introduction. The receptions of biological protection with use of entomophages and entomopathogens in conditions of granaries in relation to complex of dominant populations of phytophages of Lepidoptera of grain stocks were scientifically grounded.

Materials and methods. During 2010-2017 years of researches were investigated stocks of cereals, legumes and industrial crops for food, fodder and seminal appointments, complex of arthropods insects and mites, which related trophic and environmentally with them, and laboratory cultures of entomophages and entomopathogens. For researches were used receptions of visual (analysis of average samples) and instrumental (food and pheromone traps) monitoring, microbiological, population and statistical methods.

Results and discussion. As result of long-term researches was shown principled possibility of effective biological protection, as well control of strength of dominant complex of phytophages of Lepidoptera of grain stocks. Technological parameters and expediency of using laboratory cultures of entomophages combined with microbiological preparations have been optimized. It is important that whole arsenal of biological protection was used during critical periods of ontogenesis of insect-phytophages. This process was accompanied not only by fighter effect of operational character, but also by regulatory influence with subsequent transition of populations in long depressive state. The specific biocenotic regularity was established. It is because population of entomophages and active substances of biological preparations were characterized by pronounced aftereffect, which manifests in physiological anomalies, in particular, violation of rhythm of oogenesis with subsequent decreasing real fecundity of females and trophic activity of caterpillars. Constituent parts of original technology showed pronounced efficiency in relation to phytophages. In particular, laboratory cultures of entomophages parasitized corresponding stages of phytophages at level of $64.2 \%$. Effect and aftereffect of microbiological preparations as part of the technology were also effective. Mortality of phytophages was $70.4 \%$. As result, the biological strategy of protection of grain stocks provided total efficiency at level of $82.7 \%$ against $93.1 \%$ in chemical standard. Approbation of biological receptions has shown their manufacturability and adoption by practice of plant protection under such specific conditions.

Conclusions. The realization of technology ensures preservation of $96.6 \%$ of gross stock of grain from phytophages of Lepidoptera. 


\section{Introduction}

\section{Relevance of topic in the world}

It is generally accepted that among other indicators economic well-being of the state determine by its food stock. Particularly relevant is issue of protecting plant products in connection with latest global environmental, economic and political problems. In most cases, these problems are solved by comparatively long-term storage of harvest stocks of current year, according to existing traditions for each individual state, its size, character and consumer ability of population.

It is known that row of stress factors of biotic and abiotic origin accompany process of storage of grain and products of its processing, including in modern high-tech elevators. Often negative consequences of their manifestation acquire catastrophic character, accompanied by losses not only of gross part of harvest, but also decrease indicators of its quality. We also emphasize that over $80 \%$ of all negative factors concern to harmful activity of phytophages - insects and mites. Their species composition in granaries is more than 400 species. It should be noted that class of insects characterize by exceptional viability, reproductive activity, survival and property to withstand any stress anomalies. To these representatives of the animal world are over 400 million years old with corresponding physiological and ecological parameters of sustainability.

Many countries of the world use wide variety of receptions, means and technologies for solving problem of protection of strategic biological raw materials against expansion of arthropod-phytophages. In their composition are rather low-effective receptions of preventive character, with considerable expenditure of manual labor and other efforts, and modern technologies of total destruction of complex of arthropods, using all existing assortment of chemical preparations.

Existing assortment of preparations is characterized by rather significant level of toxicity, in relation to not only target objects, but also exhibit poisoning effect to animals and human. However, it is necessary to search real alternative technologies for protection of grain stocks and products of its processing, which involve partial or radical decrease of pesticide press in this branch, taking into account level of newest developments in the field of population ecology, genetics, toxicology and medical hygiene.

\section{Literature review}

There are technologies providing receptions from partial decrease of pesticide load to most radical approaches in the system of organic plant growing. Objective critical analysis of latest scientific and technical developments in this system was showed principal possibility of realization to known technologies, based on use of natural populations of entomophages, as means, partially restraining to expansion of phytophages in conditions of closed rooms (Drozda, Bondarenko, patent of Ukraine № 119532. Way of protection of grain and grain products against phytophages during long-term storage in the system of organic plant growing).

Among pathogens of insects are viruses, bacteria, protozoa and fungi (Moore et al., 2000). There are data about absence of side action of entomopathogens of bacterial and fungal etiology to parasites. Insects able to be as sources of accumulation and vectors of spread of entomopathogens.

Using spores of white muscardine was most common among entomopathogenic fungi (Lord, 2005). The expediency of using various microbiological preparations on basis strains 
of entomopathogenic microorganisms, which really existing in nature, mainly bacterial and fungal etiology was established experimentally (Flinn, Scholler, 2012). However, at this stage fungal entomopathogenic preparations for practical use were not registered to control of strength of the population of phytophages of grain stocks (Lord, 2005).

Most researches are aimed at studying features of mass laboratory production of cultures of entomophages - species of the genus Trichogramma sp. and Habrobracon sp. in branches of integrated protection of grain stocks and organic plant growing (Chen et al., 2013; Chimire, Phillips, 2014; Shah Alamet al., 2016). Specific predictors that allow assessing suitability of host for laboratory rearing of Trichogramma and Habrobracon, namely level of parasitizing, quantity of laid eggs by female, lifetime of entomophage, sex ratio in received posterity were developed (Drozda, 2005; Chimire, Phillips, 2014; Gavriliţa, 2015). The problems of role of nutrient media to development of phytophages and their entomophages, and action of hydrothermal conditions by them are investigated (Eslampour, Aramideh, 2016; Golizadeh et al., 2017). The exploring biology, physiology and ecology of entomophages and their hosts for increasing their reproductive potential and lifetime occupies important part of experimental researches (Drozda, 2003, 2011; Pezzini et al, 2017).

There are fragmentary researches to introduction of biological technologies with use of entomophages - parasites, predators and entomopathogens, as elements of integrated protection of plant products during long-term storage (Grieshop et al., 2006; Casada et al., 2008; Hagstrum, Subramanyam, 2009; Adarkwah et al., 2010; Scholler, 2010; Upadhyay, Ahmad, 2011; Flinn, Scholler, 2012; Drozda, Bondarenko, 2017).

Nowadays, the world mass production of useful insects for branch of grain protection is limited by three European countries - Germany, Netherlands and Switzerland. The use of entomophages in protection of grain stocks has become commercial character in Central Europe. There are several biological laboratories for mass rearing of cultures of entomophages in order to using them as element of integrated protection of grain and products of its processing in period of long-term storage against arthropod-phytophages (Scholler, 2010). At this stage, realization of technologies of biological protection of grain has not acquired scale of industrial storage. Seven species of parasites and predators are commercially available for protection of grain stocks against arthropod-phytophages in the United States of America (White, Johnson, 2010). Expert analysis was showed that the realization of technologies of biological protection in system of organic plant growing characterized by pronounced economic efficiency with certain perspectives. It is also stressed that guaranteed efficiency ensured by joint use of entomophages (Grieshop et al., 2006; Niedermayer, Steidle, 2010; Scholler, 2010).

In the countries of central and eastern Europe, the distribution has received mass production of laboratory cultures of Trichogramma in order to protecting agricultural crops, mainly in agrocenoses (Drozda, 2000; Reiliants, 2008; Gavrilitsa, 2010; Molchanova et al., 2015). Elements of biological control in protection of grain stocks are represented only fragmentarily by partial use of current spectrum of commercial microbiological preparations, predominantly bacterial etiology in mixtures with insecticides (Bondarenko, 2015).

At the same time, there are no fundamental works based on thorough exploring biology, ecology and physiology of dominant phytophages of grain stocks, trophic activity of entomophages and entomopathogens, connectivity of their life cycles. In fact, at this stage were obtained contradictory, unsustainable effects by indicators of positive result with clear trend of perspective of this direction. 
Proceeding from the above, it is obvious that qualitatively new approaches to solution of such important state problem as ensuring protection of grain stocks are needed. The authors assume that these approaches should be based on detailed exploring features of physiology and ecology of phytophages, their entomophages and entomopathogens, taking into account their life strategies, level of adaptability and ecological heterogeneity.

\section{Purpose of researches}

The main purpose of researches was assessment of level of viability of phytophages and their entomophages with original elements of their physiological monitoring, ecological valence and adaptability. On such peculiar scientific foundation were determined most important technological parameters, based on real production characteristics of level of technical equipment of granaries, periods of beginning expansion of phytophages, character of mastering ecological niches and initial manifestation of phenomenon of phytophagy. The task was set to propose of separate receptions as part of completed technologies of biological and integrated protection of grain stocks against complex of phytophages of Lepidoptera for production.

The clear technological parameters, concerning prediction of level of risk and appropriateness of use of biological receptions as part of holistic technology according to results of these researches are formulated. An important component of experimental work was determining sequence and compatibility of individual elements as part of original technology of grain protection. During researches was set task of justification not only level of protection and preservation of harvest, but also ecological aspect, namely problem of using organic product as raw material for food industry.

\section{Materials and methods}

\section{Investigational materials}

Long-term experimental researches (2010-2017 years) in warehouses of granaries for floor storage of grain and modern technically equipped modules of elevators, mainly in regions of the Forest-Steppe and Polissya of Ukraine were carried out. The main biological substrate is cereal grains with predominance of winter wheat, leguminous and industrial crops.

As means of biological control were used laboratory cultures of egg parasite of phytophages of Lepidoptera - Trichogramma evanescens Westw. (Hymenoptera, Trichogrammatidae). This parasite is reared massively in numerous bio-laboratories of Ukraine, using standard culture of Angoumois grain moth - Sitotroga cerealella Oliv. (Lepidoptera, Gelechiidae) (Drozda, parent of Ukraine № 22701. Way of mass rearing Trichogramma). As part of arsenal of biological control of phytophages was ectoparasite of caterpillars - Habrobracon hebetor Say. (Hymenoptera, Braconidae) with using known technologies of his laboratory production in our modification (Drozda, patent of Ukraine № 49250. Way of rearing laboratory populations of ectoparasite - Habrobracon hebetor Say.).

\section{Order of conducting researches}

The receptions of visual and instrumental phytosanitary monitoring of granaries and elevators were integral part of technology of grain storage and its protection. Instrumental 
monitoring has assumed use of various technical adaptations for catching individual stages of insects. In addition, we used pheromone traps with set of modern assortment of targeted dispensers.

The obtained results of phytosanitary monitoring served as basis for choice of means and receptions of control of strength of phytophages of Lepidoptera, taking into account such universal indicator as threshold level of harmfulness. At the same time, level of domination of individual phytophages, density of their populations, relative prevalence, potential and real harmfulness were established.

In course of industrial tests were conducted receptions of manual resettlement of entomophages, taking into account fragmentarity and hearths of initial expansion of various grain substrates by phytophages. Starting populations of entomophages were reared by original author's technology, aimed at induction of such characteristics as motor activity of adult females and their search ability. This is essential methodological feature of proposed technology.

Trichogramma and Habrobracon - entomophages of first class of quality, previously adapted to conditions of closed rooms, was exhibited in special containers. The norm of resettlement of Trichogramma was 10,000 individuals per $1 \mathrm{~m}^{2}$. The reception of resettlement of adults of Habrobracon at period of beginning emergence of caterpillars of phytophages of Lepidoptera of third age was carried out in norm of 15-20 individuals per $1 \mathrm{~m}^{2}$ of area of grain substrate.

In addition, character of oogenesis of females of entomophages, functioning in pro- and synovigenic regimes was taken into account. As rule, the starting populations of entomophages only first class of quality were used. Evaluation predictors are based to level of viability, motor activity of females of entomophages in process of searching certain stages of development of phytophages.

We accounted pronounced species-specific reaction of caterpillars to acting substances of biological preparations. It's biological and ecological basis for using fungal entomopathogens in form of preparations. This allowed entering two microbiological preparations as part of technology - Boverin and Petsilomin, created on basis of entomopathogenic fungi of white muscardine (Beauveria bassiana (Bals.) Vuill.) and pink muscardine (Paecilomyces farinosus (Holmsk.) A.H.S. Br. \& G. Sm.) (Deuteromycetes, Fungi Imperfecti).

Usually entomopathogenic preparations were used sequentially after resettlement of entomophages in event of existence of threat of increasing strength of populations of phytophages of Lepidoptera. It should be noted that their acting substances do not have pronounced entomocidal activity in relation to entomophages. The interval between these receptions was from 10 to 14 days. The hearths of spreading target phytophages were treated by working suspensions of entomopathogenic preparations. As rule, large quantity of initial material in laboratory and production experiments was involved, which allow making objective conclusions about efficiency of conducted receptions.

\section{Description of methods, installations}

Special engineering constructions are aimed at protection of biomaterial against mechanical damage and influence of other stress factors. In addition, these modules capable of supporting optimal regimes for daughter populations, nutrition in form of specific carbohydrate-protein diet, mating and unhindered resettlement in thickness of grain in places of concentration of corresponding stages of phytophages. In most cases, natural honey and hemolymph of caterpillars of senior ages of owlet moths as diet were used. 
Developed devices are specific plastic containers with corresponding blocks of multifunctional use. Modules with biomaterial are designed for its resettlement on surface of grain. Their construction is protected by patents of Ukraine.

\section{Processing research results}

The obtained digital material was processed statistically. The statistical processing results of phytosanitary monitoring on infestation of grain by phytophages with use of program Excel was involved. Levels of dominance and density of populations of phytophages were established. The level of dominance was determined by the formula:

$$
\mathrm{D}=100 \times \frac{\mathrm{k}}{\mathrm{K}},
$$

where $\mathrm{D}$ - the degree of dominance of phytophages; $\mathrm{k}$ - quantity individuals of certain species; $\mathrm{K}$ - total quantity of all collected species.

The density of populations of phytophages of grain stocks was determined by the formula:

$$
\mathrm{V}=\frac{\mathrm{k}}{\mathrm{n}}
$$

where $\mathrm{V}$ - density of populations of phytophages in samples; $\mathrm{k}$ - the sum of all individuals of species in samples; $\mathrm{n}$ - quantity of investigated samples.

For determining indicators of linear correlation $(\mathrm{Y}=\mathrm{a}+\mathrm{b} \cdot \mathrm{X})$ of obtained experimental data was used computer program of «Statgraphics plus».

\section{Results and discussion}

Researches of species composition of arthropods-phytophages of grain stocks. As results of long-term researches have shown, the total fund of phytophages of grain stocks was over 80 species of arthropod, which belong to 3 classes (Arachnida, Entognatha, Insecta), 9 orders (Psocoptera, Pseudoscorpionida, Thysanura, Sarcoptiformes, Trombidiformes, Acarina, Mesostigmata, Coleoptera, Lepidoptera), 29 families (Psocidae, Atropidae, Cheliferidae, Lepismatidae, Acaridae, Glycyphagidae, Cheyletidae, Tydeidae, Pediculoididae, Parasitidae, Lealaptidae, Curculionidae, Tenebrionidae, Cucujidae, Dermestidae, Cryptophagidae, Bostrychidae, Anobiidae, Ostomatidae, Nitidulidae, Ptinidae, Bruchidae, Lathridiidae, Notoxidae, Cleridae, Tineidae, Gelechiidae, Pyralidae, Noctuidae). During phytosanitary monitoring of granaries and elevators, it was established that percentage of species of Lepidoptera was about $30 \%$ from general structure of phytophages. Among phytophages of grain stocks from order of Lepidoptera were observed such species as Plodia interpunctella Hb., Ephestia ellutela Hb., E. kuehniella Zell., Pyralis farinalis L. (Pyralidae), Sitotroga cerealella Oliv. (Gelechiidae), Nemapogon granella L., Tineola bisselliella Humm., Tinea translucens Meyr., Haplotinea ditella P. et Diak., Niditinea fuscipunctella Hw. (Tineidae). Detailed exploring their biology, physiology, and ecology (Table 1) showed that all of them develop in polyvoltinic regime. 


\begin{tabular}{|c|c|c|}
\hline 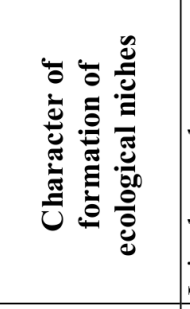 & 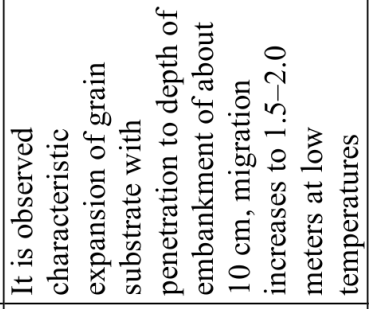 & 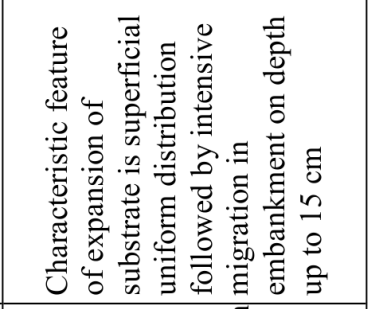 \\
\hline 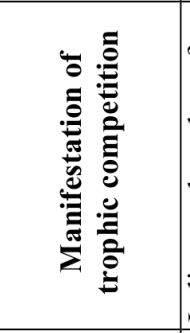 & 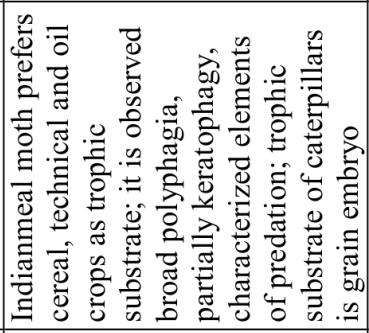 & 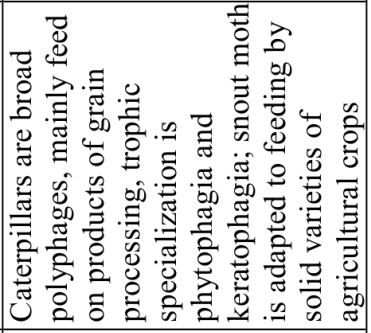 \\
\hline 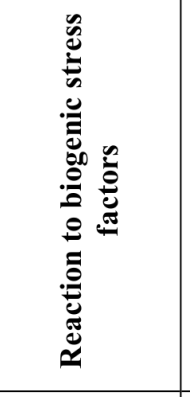 & 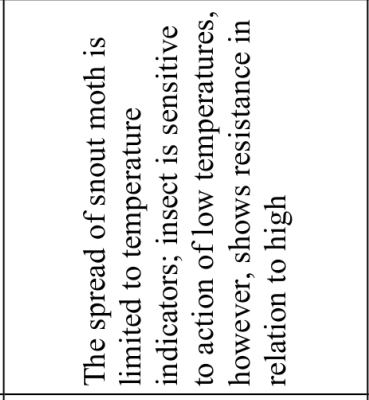 & 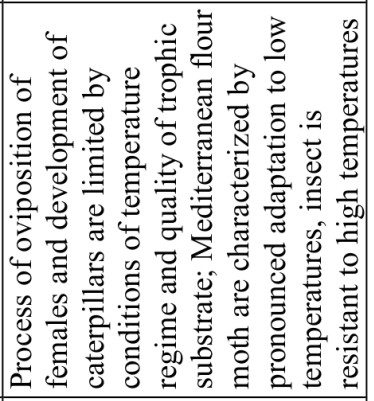 \\
\hline 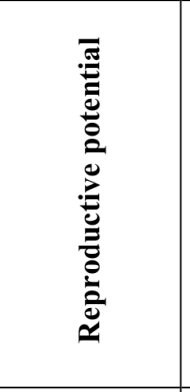 & 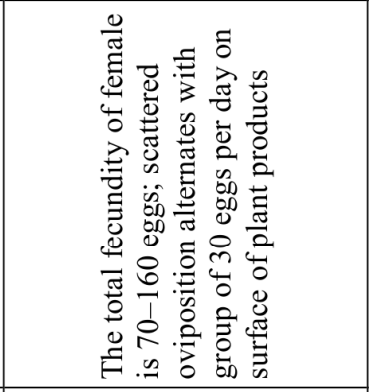 & 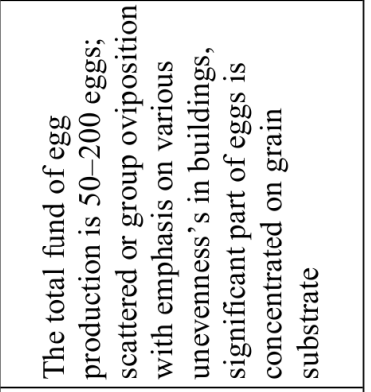 \\
\hline 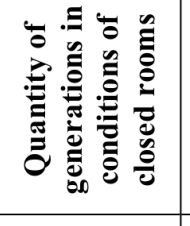 & 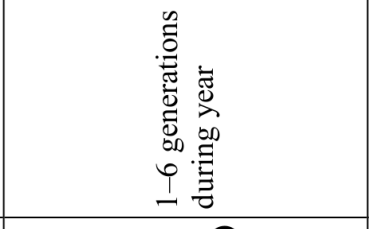 & 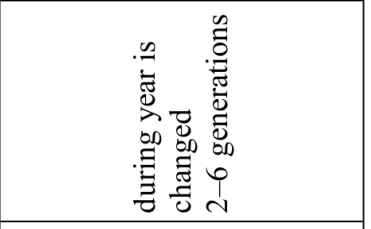 \\
\hline 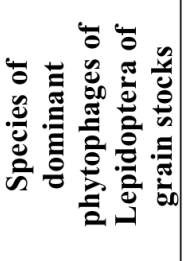 & 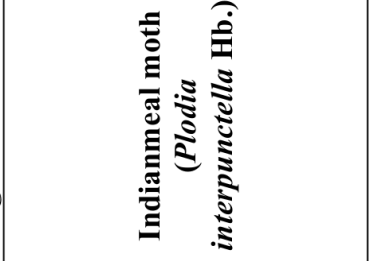 & 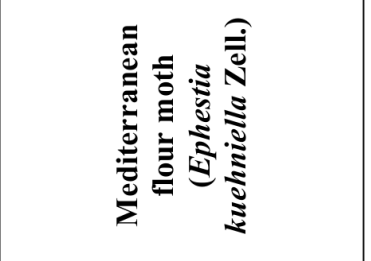 \\
\hline
\end{tabular}




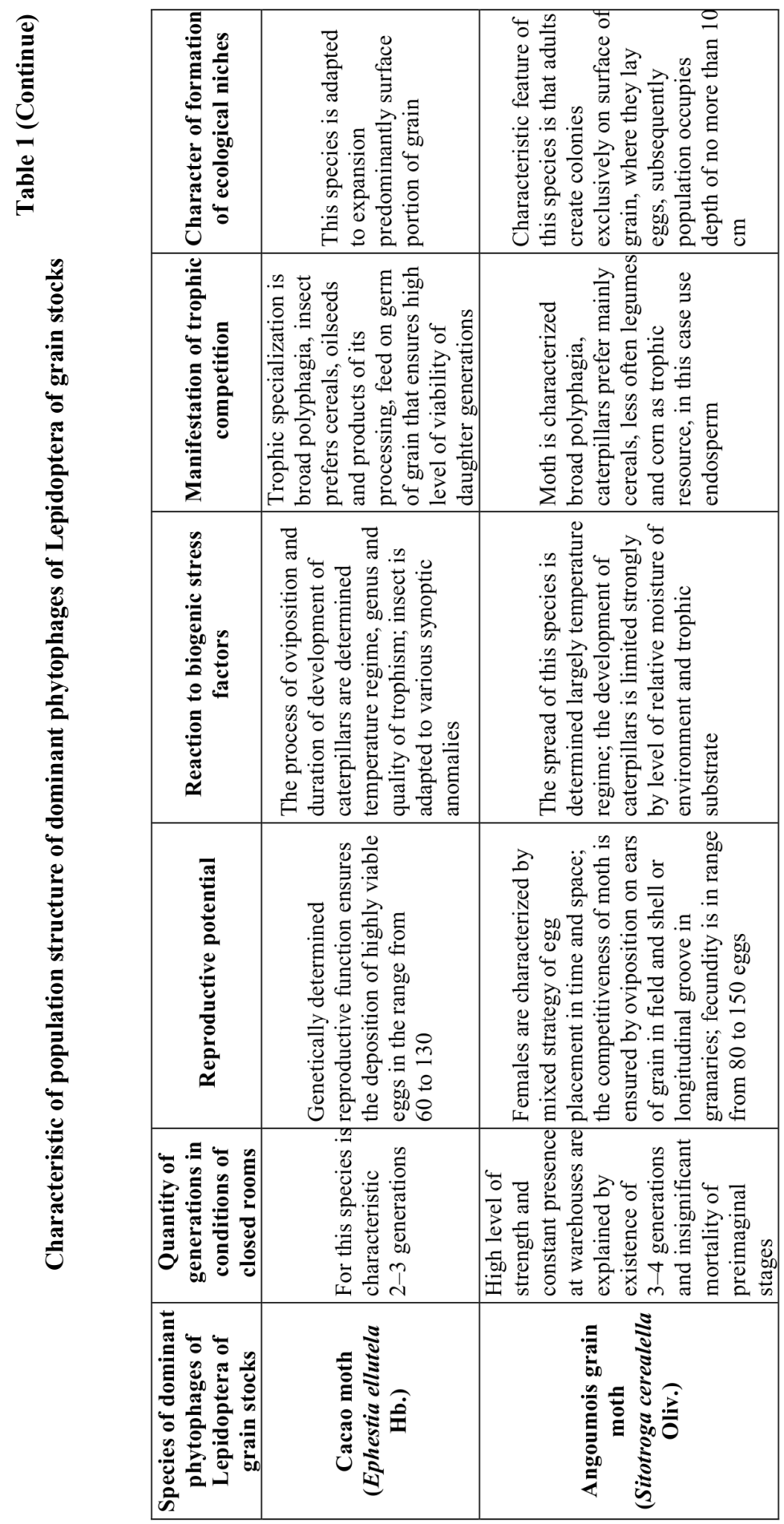


苞

\begin{tabular}{|c|c|c|}
\hline 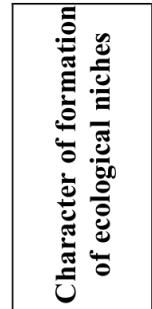 & 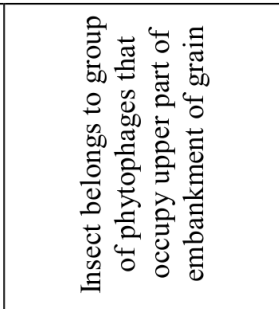 & 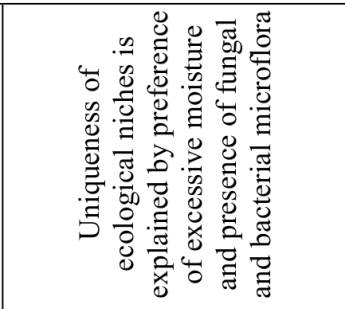 \\
\hline 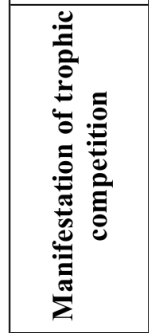 & 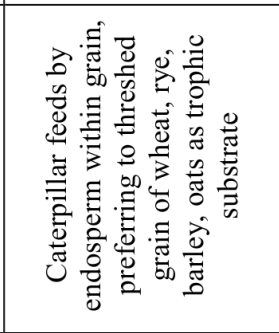 & 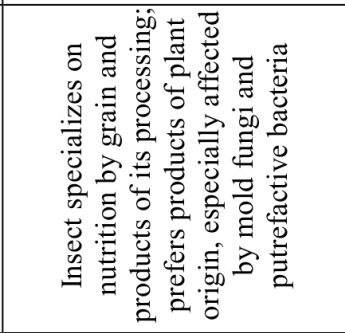 \\
\hline 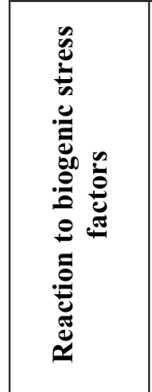 & 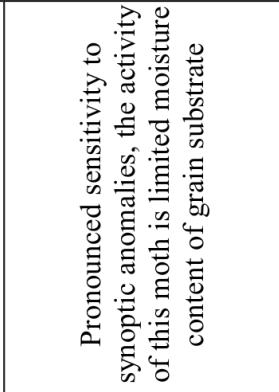 & 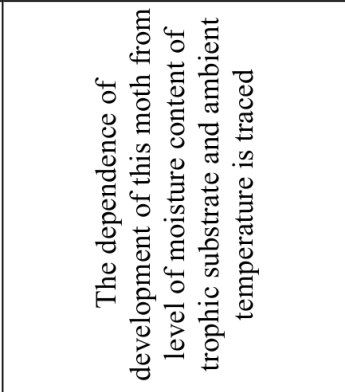 \\
\hline 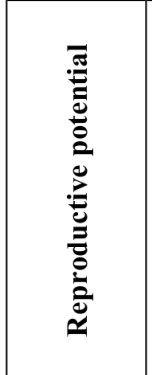 & 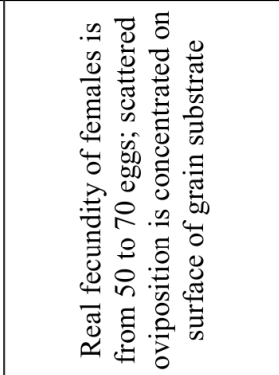 & 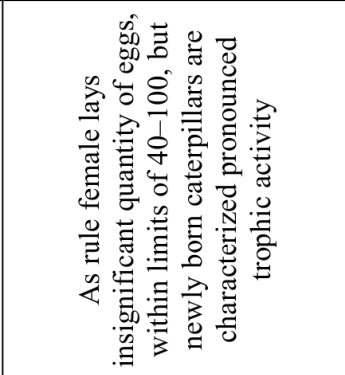 \\
\hline 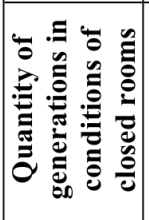 & 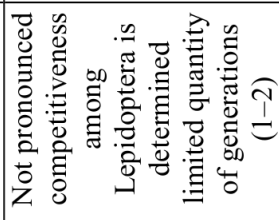 & 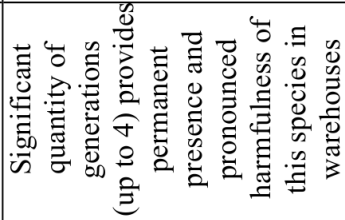 \\
\hline 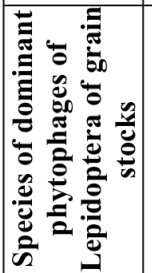 & 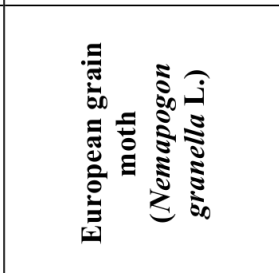 & 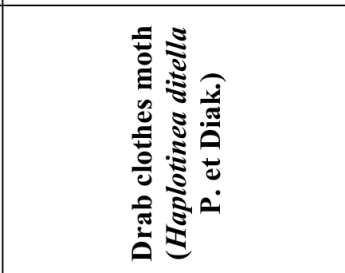 \\
\hline
\end{tabular}




\begin{tabular}{|c|c|c|c|}
\hline \multirow{6}{*}{ 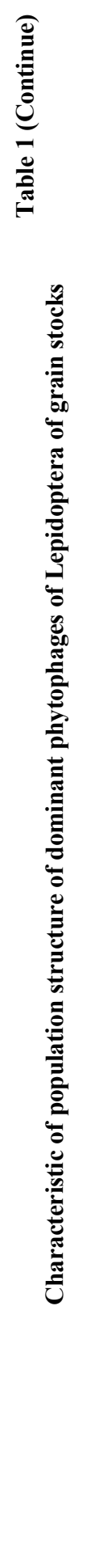 } & \multirow{6}{*}{ 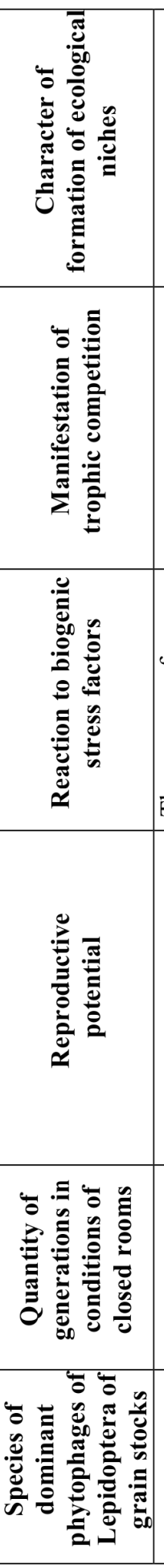 } & \multirow{6}{*}{ 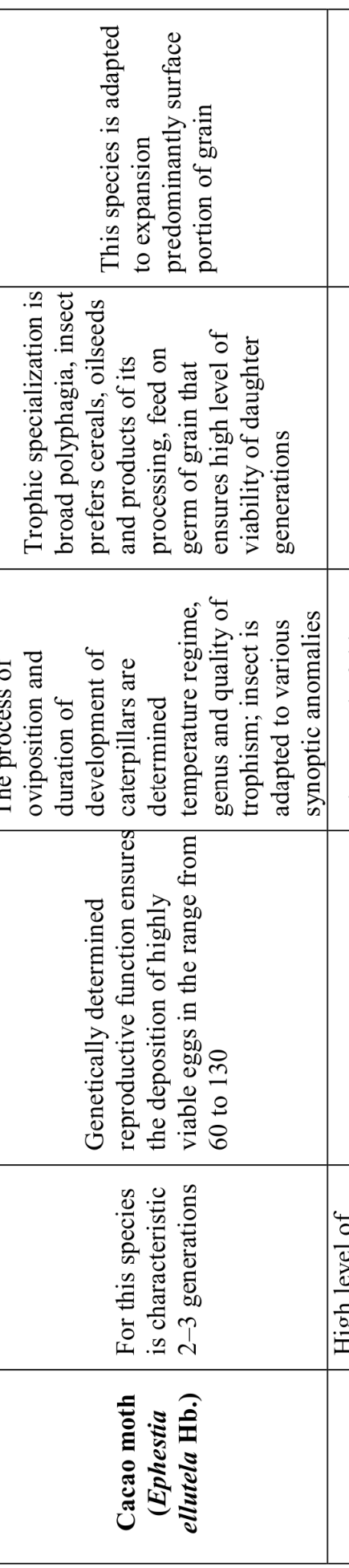 } & \multirow{2}{*}{ 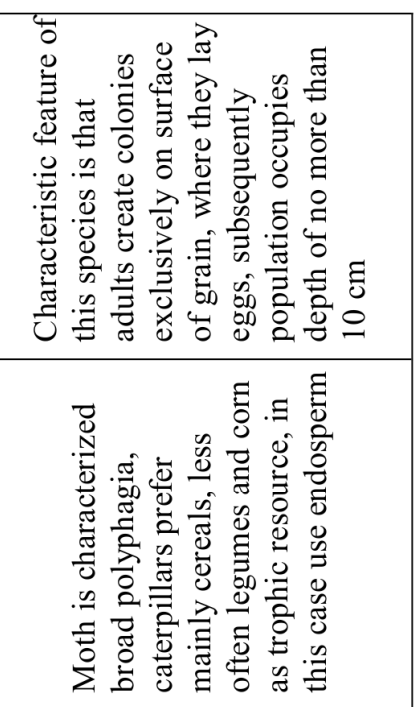 } \\
\hline & & & \\
\hline & & & 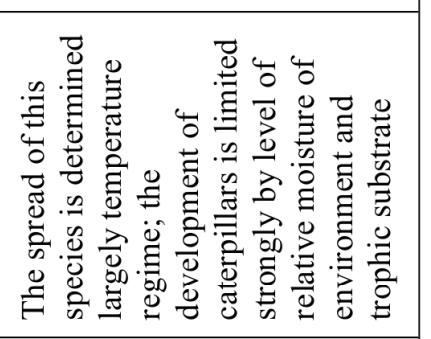 \\
\hline & & & 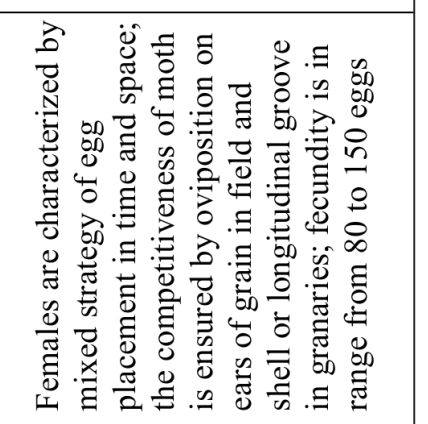 \\
\hline & & & 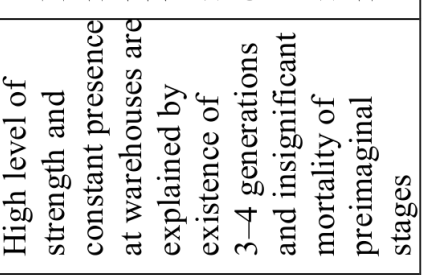 \\
\hline & & & 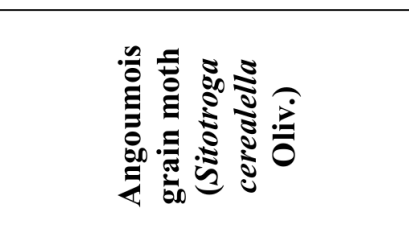 \\
\hline
\end{tabular}


Their development are limited not so much trophic factor, so much hydrothermal parameters. It is also established that the lower limit for development of populations of most species of phytophages of Lepidoptera of grain stocks is from 10 to 15 degrees. It means that period of active nutrition and harmfulness is limited by the summer-autumn season. Two expressed peaks of trophic and flight activity, intensive increase of strength of Lepidoptera in June and September were observed.

\section{Experimental researches of the author's technology of biological protection of grain against phytophages of Lepidoptera}

These materials were served as basis for optimization of receptions of biological protection of grain against phytophages (Table 2). In fact, the first three years of researches against background of high level of strength of phytophages of Lepidoptera were conducted. It was observed domination of such species as Indian meal moth (Plodia interpunctella $\mathrm{Hb}$.), cacao moth (Ephestia ellutela $\mathrm{Hb}$.), Mediterranean flour moth (E. kuehniella Zell.) (Pyralidae) and Angoumois grain moth (Sitotroga cerealella Oliv., Gelechiidae). It is over $85 \%$ of the total fund of Lepidoptera. The technology with sequential using Trichogramma evanescens Westw. (Trichogrammatidae), entomopathogenic fungal preparations and Habrobracon hebetor Say. (Braconidae) is realized for transition of populations of these phytophages to prolonged depressive state. It is this sequence was maximized biological fighter activity of different stages.

Special meaning was attached to resettlement of Trichogramma that is important reception, taking into account prevention of spreading caterpillars of phytophages in range from 35 to $65 \%$. This reception is one of the most effective, ecologically safe and characterize by pronounced economic importance. As rule, it is enough to hold two receptions of resettlement of Trichogramma in period of beginning process of mass oviposition at indicators from one to three threshold levels, based on materials of pheromone and visual monitoring. This period lasts from 10 to 12 days. Obviously, reception is prevented potential harmfulness of phytophages of Lepidoptera.

As result, Trichogramma parasitized from 43.4 to $68.7 \%$ eggs, mainly ineffective part of populations of phytophages of Lepidoptera. The most viable females of Trichogramma parasitized from 16.8 to $34.6 \%$ of effective part of populations of snout moths and moths. This is most significant part of researches that indirectly characterizes heterogeneity of the starting populations of phytophages, trophic and ecological specialization of Trichogramma. It also should be noted that significant part of ovipositions of effective population of phytophages died as result of act of nutrition of females of Trichogramma by their hemolymph. It is from 13.4 to $18.6 \%$ of the total stock of eggs. Trichogramma does not lay eggs in such eggs of phytophages. As result, phytophages are eliminated.

However, remainder part of populations of Lepidoptera represents real threat of increasing harmfulness, given high initial level of strength of phytophages. Therefore, one reception of local treatment of grain substrate with aqueous solution of entomopathogenic fungal preparation - Boverin was carried out. This reception was conducted only in initial period of mass emergence of caterpillars of Lepidoptera. The titer of viable spores of fungus of white muscardine was 6.3 billion in $1 \mathrm{~g}$. Shelf life of preparation did not exceed 2 months. The efficiency of this reception ranged from 48.4 to $68.5 \%$. 
— Food Technology-

ำ

\begin{tabular}{|c|c|c|c|c|c|}
\hline \multicolumn{2}{|c|}{ 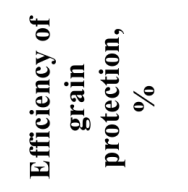 } & $\begin{array}{l}\hat{j} \\
\infty\end{array}$ & $\bar{a}$ & 1 & $\tilde{n}$ \\
\hline \multicolumn{2}{|c|}{ 离 } & $\stackrel{\sigma_{n}}{n}$ & $\stackrel{\simeq}{=}$ & $\begin{array}{l}0 \\
\stackrel{+}{d}\end{array}$ & $\stackrel{?}{=}$ \\
\hline \multirow{2}{*}{ 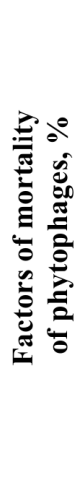 } & 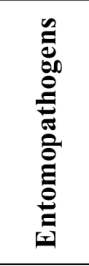 & $\stackrel{+}{\gtrless}$ & $\stackrel{m}{*}$ & $\begin{array}{l}N \\
n\end{array}$ & $\stackrel{0}{-}$ \\
\hline & 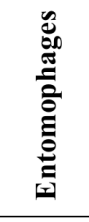 & t̃ & $\vec{i}$ & $\tilde{i n}$ & $\cong$ \\
\hline \multirow{2}{*}{ 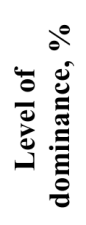 } & $\overline{\bar{\theta}}$ & $\stackrel{0}{\tilde{\lambda}}$ & $\stackrel{\infty}{\stackrel{\infty}{\Omega}}$ & $\overrightarrow{\tilde{d}}$ & 1 \\
\hline & 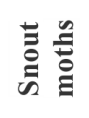 & fó & $\begin{array}{l}\text { Oे } \\
\dot{\infty}\end{array}$ & $\frac{\partial}{i}$ & 1 \\
\hline \multicolumn{2}{|c|}{ 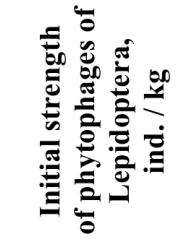 } & $\stackrel{0}{\grave{\lambda}}$ & $\hat{m}$ & $\begin{array}{l}\infty \\
v^{n} \\
f\end{array}$ & 1 \\
\hline \multicolumn{2}{|c|}{ 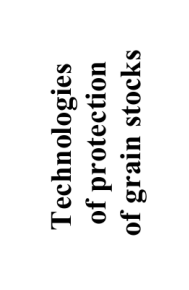 } & 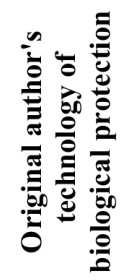 & 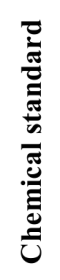 & U⿺ & $\stackrel{n}{0}$ \\
\hline
\end{tabular}


As our researches have shown, the period of emergence of caterpillars from eggs lasts from 23 to 32 days. The viable part of caterpillars after realization of these two receptions represented also immediate threat, primarily as factor of growth populations of phytophages. In this case, the application of laboratory culture of Habrobracon, exclusively of first class of quality was justified. Adults of Habrobracon function during long period, namely from 17 to 24 days, in contrast to Trichogramma. It is essential that process of oogenesis of females also characterized by high activity and duration. It was provided parasitization of caterpillars of phytophages of Lepidoptera at level from 63.2 to $74.8 \%$, given high motor and search ability of Habrobracon. The tactic of their operational control are timed strictly to this period due to specific rhythmics of ontogeny of these phytophages, in particular their trophic binary activity.

The status of phytophages for Angoumois grain moth (Sitotroga cerealella Oliv., Gelechiidae) and European grain moth (Nemapogon granella L., Tineidae) in second period of activity of Lepidoptera actually was lost. Only single individuals were noted. The results of phytosanitary monitoring indicated about trend of increase of strength of dominant species of snout moths, which is observed in beginning September. It created certain threat of hearth spread. These materials were basis for application of reception of single-entry resettlement of Trichogramma as restraining and regulatory factor, followed by continuous treatment of grain substrate by entomopathogenic fungal preparation - Petsilomin. Acting substance of preparation is spores of pink muscardine with titer of 5.5 billion in $1 \mathrm{~g}$. The choice of this preparation was due to much higher level of adaptability to low temperatures and pronounced entomocidal activity, in comparison with Boverin. The terms of treatment were analogical to first receptions. The level of mortality of different stages of Lepidoptera was within of $56.9-82.3 \%$.

\section{Discussion of research results}

The proposed strategy provides acceptable efficiency of sharp decline of starting populations of phytophages of Lepidoptera with use entomophages and entomopathogens. The expediency of introducing further fighter technologies with use biological receptions depends on quality phytosanitary monitoring for determine occupancy and infestation of grain stocks by phytophages. Trichogramma is mandatory reception in all cases regarding practical realization of technologies of biological protection of grain at moderate indicators of strength of phytophages of Lepidoptera. It is explained by comparative simplicity of obtaining unlimited quantity of biomaterial, its cheapness, and small size of adults.

By results of researches, important biocenological aspect was established. This aspect is manifested in fact that the deceased populations acted as source of accumulation, passive and active spread by inoculum of fungi in grain substrate. Beetle-phytophages (Coleoptera), accompanying insects and adults of Habrobracon were as vectors. The phenomenon of partial process of self-regulation of this particular ecological niche by rather pronounced activity of daughter generations of entomophages, and circulation of spores and vegetative bodies of entomopathogenic fungi was noted.

The absence of phenomenon of formation of resistant populations of target phytophages was established. According to the results of long-term researches, this fact is important point in using entomopathogenic fungi. The evolutionary saprophytic genetic life strategy of these entomopathogens in conditions of closed rooms is practically not realized. It is due to total absence of relevant trophic substrate. Consequently, adaptation and directed selection form only entomocidal activity of preparations. In the authors' opinion, proposed technology is main integral part of organic plant growing, taking into account 
sanitary-hygienic characteristic of these preparations with absence of negative action to warm-blooded, human and entomophages. Important role is played by the fact that these preparations and authoring receptions of using entomophages are intellect-product of domestic technologies.

\title{
Conclusions
}

The strategy of scientific search to original technical solutions was formulated on the grounds of expert analysis of condition of branch of grain protection during its long-term storage. They are aimed at solving important state problem, related to radical ecologization of existing technologies of protection of grain stocks, predominantly pesticide receptions.

The conducted experiments showed principal possibility of adaptation of laboratory cultures of species of the genus Trichogramma and Habrobracon for specific conditions of closed rooms. The phenomenon of trophic interaction of these entomophages with target species of phytophages (moths and snout moths) was established. The norms, terms and multiplicities of application of entomophages during storage of grain based on worked parameters were established. Various technical improvements, aimed at preserving biomaterial and their long-term contact with phytophages for optimization parameters of realization of biotic potential of entomophages were suggested.

Experimentally were established feasibility and efficiency of using entomopathogenic fungal preparations - Boverin and Petsilomin for destabilize structure of populations of phytophages. The operational sequence of application of entomophages and biopreparations was shown. For the first time have been studied in detail features of biology, physiology and ethology of dominant species of phytophages, established critical periods in their ontogeny. This made it possible to effectively influence on processes of reproduction and spread of phytophages. A range of problems was defined that must be studied for increasing efficiency of technologies of biological protection with simultaneous search of promising species of entomophages and entomopathogens for needs of production.

\begin{abstract}
Acknowledgements
The authors would like to thank management and engineering staff of agricultural enterprises for opportunity to conducting experimental researches (Hhutianskyi elevator; Poltava Grain Receiving Enterprise; Poltava State Agricultural Experimental Station of Institute of Swine Breeding and Agro-Industrial Production named after M. I. Vavylov). The authors also express their gratitude to Bondariev Yevgenii - engineer of the 2nd category of «Radionix» for designing and development of modulescontainers for resettlement of entomophages in warehouses.
\end{abstract}

\section{References}

1. Adarkwah Charles, Buttner Carmen, Reichmuth Cristoph, Scholler Matthias (2010), Ability of the larval ectoparasitoid Habrobracon hebetor (Say., 1936) (Hymenoptera: Braconidae) to locate the rice moth Corcyra cephalonica (Stainton, 1965) 
(Lepidoptera: Pyralidae) in bagged and bulk stored rice, Journal of Plant Diseases and Protection, 117 (2), pp. 67-70.

2. Bondarenko I.V. (2014), Chlenistonogie vrediteli zapasov zerna v zernokhranilishchakh Poltavskoi oblasti, Zashchita rastenii, In-t IZR, Belarus, 38, pp. 183-195.

3. Bondarenko I.V. (2014), Khimicheskii i biologicheskii kontrol chislennosti vreditelei khlebnykh zapasov, Visnyk Poltavs'koyi derzhavnoyi ahrarnoyi akademiyi, 2, pp. 161164.

4. Bondarenko I.V., Sekun M. P., Vlasova O. H. (2016), Shkidnyky zerna kolosovykh kul'tur $\mathrm{v}$ period zberihannya, Zakhyst $i$ karantyn roslyn, 62, pp. 64-71.

5. Bondarenko I.V. (2015), Sravnitelnaia toksichnost insektitsidov i biopreparatov dlia osnovnykh vreditelei zerna v period khraneniia v Ukraine, Vestnik Prikaspiia, 2 (9), pp. 33-37.

6. Bondarenko I.V. (2015), Vydove riznomanittya chlenystonohykh-shkidnykiv zerna kolosovykh kul'tur v period zberihannya, Zbirnyk naukovykh prats' Natsional'noho naukovoho tsentru «Instytut zemlerobstva NAAN», 3, pp. 69-76.

7. Bondarenko I. V. (2015), Zaselenist' ta zarazhenist' zapasiv zerna shkidlyvymy chlenystonohymy, Selektsiya i nasinnytstvo, 108, pp. 83-91.

8. Casada M. E., Ram M. S., Flinn P. W. (2008), Thermal design of shipping containers for beneficial insects, Appl. Eng. Agric, 24, pp. 63-70.

9. Chen Haoliang, Zhang Hongyu, Kun Yan Zhu, Throne James (2013), Performance of diapausing parasitoid wasps, Habrobracon hebetor, after cold storage, Biological control, 64(3), pp. 186-194.

10. Chimire M. N., Philips T. W. (2014), Oviposition and reproductive performance of Habrobracon hebetor (Hymenoptera: Braconidae) on six different Pyralid host species, Ann. Entomol. Sok. Am., 107(4), pp. 809-817.

11. Drozda V., Bondarenko I., Zagaiko O. (2017), Regulatory and modifying role of natural populations of entomophages in biocenoses of the exclution zone of the Chernobyl nuclear power plant, Agrobiodiversity for improving nutrition, health and life quality, 1, pp. 102-107.

12. Drozda V.F., Bondarenko I.V. (2017), Zhiznennaia strategiia dominiruiushchikh fitofagov zapasov zerna, Zemledelie i zashchita rastenii, In-t IZR, Belarus, 3 (112), s. $16-20$.

13. Drozda V.F. (2003), Dodatkove zhyvlennya imaho yizdtsiv. Osoblyvosti rozmnozhennya, formuvannya statevoyi produktsiyi, poshyrennya, teoretychni ta praktychni aspekty problemy, Zakhyst roslyn, 10, pp. 9-11.

14. Drozda V.F., Kocherha M.O. (2011), Ekolohichni ta biotekhnolohichni problemy vyroshchuvannya ta vykorystannya vydiv rodu Trichogramma, Ukrayins'kyy entomolohichnyy zhurnal, pp. 25-27.

15. Drozda V.F. (2000), Kontseptual'ni problemy biolohichnoho zakhystu roslyn, Visnyk ahroekolohichnoyi akademiyi Ukrayiny, pp. 314-316.

16. Drozda V.F. (2005), Operatsiyna tekhnolohiya rozvedennya ta vykorystannya synovihennykh entomofahiv - skladovoyi chastyny intehrovanykh system zakhystu roslyn, Mizhnarodnyy naukovo-praktychnyy forum «Osnovy molekulyarnohenetychnoho ozdorovlennya lyudyny i dovkillya», Kyyiv, pp. 50-52.

17. Eslampour Leila, Aramideh Shahram (2016), Adult longevity, fertility and sex ratio of Habrobracon hebetor (Say) (Hymenoptera: Braconidae) parasitizing Ephestia 
kuehniella (Zeller) (Lepidoptera: Pyralidae): effect of host artificial diets, Journal of Entomology and Zoology Studies, 4 (1), pp. 189-192.

18. Flinn P.W., Scholler M. (2012), Biological control: Insect pathogens, parasitoids, and predators, In: Hagstrum D. W., Phillips T. W., Cuperus G., editors, Stored Product Protection, S156, Manhattan, KS: Kansas State University, pp. 203-212.

19. Fursov V.N. (2001), Biologicheskii metod zashchity rastenii: mezhdunarodnye issledovaniia i prioritetnoe znachenie taksonomii, Vestnik zoologii, 35 (3), pp. 97-101.

20. Gavriliţa Lidia (2015), Biological protection of stored grain products against the moth's complex, Muzeul Olteniei Craiova, Oltenia. Studii şi comunicări, Stiinţele Naturii, 31, 2, pp. 129-134.

21. Gavrilitsa L.F. (2010), Vliianie sposoba razvedeniia na effektivnost trikhogrammy, Zashchita i karantin rastenii, 2, pp. 35-36.

22. Golizadeh A., Alikhani M., Hassanpour M., Enkegaard A., Rafiee-Dastjerdi H., Razmjou J. (2017), Comparative biology and life table of Habrobracon hebetor (Hymenoptera: Braconidae) on Anagasta kuehniella (Lepidoptera: Pyralidae) at five constant temperatures, International Journal of Pest Management, 63 (4), pp. 364-370.

23. Grieshop M. J., Flinn P. W., Nechols J. R. (2006), Biological control of Indianmeal moth (Lepidoptera: Pyralidae) on finished stored products using egg and larval parasitoids, I. Econ. Entomol., 99, pp. 1080-1084.

24. Hagstrum D.W., Subramanyam Bh. (2009), Stored product insect resource, AACC International, St. Paul, Minnesota.

25. Lord J.C. (2005), Low humidity, moderate temperature, and desiccant dust favor efficacy of Beauveria bassiana (Hyphomycetes: Moniliales) for the lesser grain borer, Rhyzopertha dominica (Coleoptera: Bruchidae), Biological control, 34, pp. 180-186.

26. Molchanova E. D., Sheikina E. B., Gorodetskii S. A. (2015), Optimizatsiia korma dlia vyrashchivaniia melnichnoi ognevki, Nauchno-prakticheskii tsentr NAN Belorussii po zemledeliiu, Sbornik nauchnykh trudov «Zashchita rastenii», 39, pp. 191-196.

27. Moore D., Lord J.C., Smith S.M. (2000), Pathogens, In: Subramanyam B. and Hagstrum D. W. (eds.), Alternatives to pesticides in stored-product entomology, Kluwer, Boston, pp. 191-227.

28. Niedermayer S., Steidle J.L. M. (2010), Some like it hot - some not: Differences in temperature preference of two parasitic wasp species, International European Symposium on Stored Product Protection «Stress on chemical products», 429, pp. 3133.

29. Pezzini C., Jahnke S.M., Köhler A. (2017), Morphological characterization of immature stages of Habrobracon hebetor (Hymenoptera: Braconidae) ectoparasitoid of Ephestia kuehniella (Lepidoptera: Pyralidae), Journal of Hymenoptera Research, 60, pp. 157-171.

30. Reiliants N.V. (2008), Biologicheskoe obosnovanie primeneniia Trichogramma evanescens Westw. dlia reguliatsii chislennosti Helicoverpa armigera $\mathrm{Hb}$. na tomatakh i sakharnoi kukuruze, Dissertatsiia na soiskanie uchenoi stepeni doktora biologicheskikh nauk, IZR i ekologicheskogo zemledeliia, Keshineu.

31. Scholler Matthias (2010), Prospects for biological control of stored-product pests, International European Symposium on Stored Product Protection «Stress on chemical products», 429, pp. 25-31.

32. Selitskaia O.G., Mitina G.V., Shchenikova A.V., Choglokova A.A., Levchenko M.V. (2016), Vliianie letuchikh soedinenii entomopatogennykh gribov na povedencheskie reaktsii vreditelei zapasov, Vestnik zashchity prirody, 3 (89), pp. 150-152. 
33. Shah Alam, Zintul Alam, Syed Nurul Alam, Ramiz Uddin Miah et al. (2016), Host suitability of Bracon hebetor Say. on different lepidopterous host larvae, Academic Journal of Entomology, 9 (3), pp. 41-50.

34. Upadhyay R.K., Ahmad S. (2011), Management strategies for control of stored grain insect pests if farmer stores and public warehouses, World Journal of Agricultural Sciences, 7 (5), pp. 527-549.

35. White J., Johnson D. (2010), Vendors of beneficial organisms in North America, University of Kentucky Cooperative Extension Service, Entfact. 